\title{
The Visual Elements of a Pop-up Page in "LiburanTerbaik" Picture Book
}

\author{
Shoumil Alifa Cahyani ${ }^{1}$, Deny Tri Ardianto ${ }^{2}$, Nooryan Bahari ${ }^{3}$ \\ \{ shoumilalifa@student.uns.ac.id ${ }^{1}$, denytri@staff.uns.ac.id² ${ }^{2}$ \& \\ nooryanbahari@staff.uns.ac.id $\left.{ }^{3}\right\}$ \\ ${ }^{1,2.3}$ Universitas SebelasMaret, Surakarta, Indonesia
}

\begin{abstract}
Picture book is one of the simple work of fiction is seen in terms of language, the vocabulary of children have limits in accordance with the age and depth of story ideas lifted from everyday events.In the picture book, no need to describe the character in detail, because everything is already supported by existing visualization. Analysis of visual elements on the pop-uppage in a "LiburanTerbaik"picture book aims to describe and to explain the visual elements contained in the pop-up page picture book. This research is a descriptive qualitative research, and source data obtained by observation. The research results showed that pop-up illustration in "LiburanTerbaik"picture book mostly has elements of visual elements, namely color, line, shape, space, texture and typeface. Although some illustrations do not have a visual element, they are still clearly described.
\end{abstract}

Keywords: visual element, pop-up, picture book

\section{INTRODUCTION}

Book are one of the important media to increasing attitude and knowledge. But unfortunately,literacy in Indonesia is very low and yet here comes a young generation of young children. In Indonesia book still viewed as luxury items and reading activities are regarded as useless.Early education for children is from parents or family. This is where the actual starting point of interest in reading can be grown. One way is to familiarize the child recited a picture book.Children particularly from birth to age 6 must be on the focus of children's books with their curiosity, desire of exploration, sincerity, dynamism, enthusiasm, imagination and creativity, and with their nature which rejects advice and command[1]. The media picture book is a simple promotional tools are easy to use, contain a reflection of life, habits, and beliefs that are easily understood by the community, in the form of images, or a combination of both. In picture books, words and pictures invite reader to create literal realities in the world to correspond with them. Picture books define the range of canonical characters, which reflect our modes of behaving, and thus they provide a map of possible roles and possible worlds[2].

Picture book is a book featuring child as the main character, and the target readers are children. Now this picture book has many forms, not just the book as the book most (2 dimensions), but also a pop-up book (3 dimensions). Any book type range from a fairy tale 
story book, science stories, until interactive story book where in it other than as a story book, a book at once can also be dyed, even written numbers and letters. "LiburanTerbaik"picture book is one of the publisher PT. LubangKelinci Indonesia publications or better known as Rabbit Hole."LiburanTerbaik" picture book includes the second book in the series "mengenalhurufdengancaramenyenangkan" after the book "AsalMulaNamaku" which is recommended for children aged 3-7 years. What distinguishes "LiburanTerbaik" picture book with another Rabbit Hole is in this book comes with a pop-up page and also lift the flap page. While picture books, magazine, and even advertisements could provide the stimuli for production activities, pop-up and movable books offer some unique features which make them well-suited for early group literacy instruction. Pop-up books are engaging, and they hold children's attention[3].

In one illustrated page of picture book, images and text together into a communicative action. To be able to communicate visually, the use of visual elements can support the design of the illustration. Especially in making a picture book for children. Mentioned that,to construct an iconographic analysis of the images contained in a contemporary or postmodern picture book, students would be begin by creating an inventory of the objects, characters or actors, design features, and other images and visual elements of the book[4]. It also described in earlier research,given the potential importance of illustrations in character development, young children reading (or listening to) picture books must attend not only to the words of stories, but also to visual information if they are to understand the characters they meet in picture books[5]. Also, restrictions on the age of children as readers must be given attention.Although children's picture books have always been used to support young children's reading skills, and although they are slowly being recognized as powerful implements for visual literacy, they have been largely neglected as a path toward children's emotional development[6]. Thus, in this paper will be examined regarding the visual elements on the pop-up page illustrations in a "LiburanTerbaik"picture book, which is the target of this book itself is 3-7 years old child. Visual elements to be used in examining the illustrations popuppage "LiburanTerbaik" picture book i.e. color, line, shape, space, texture and typeface.

\section{METHOD}

The study of visual elements on a "LiburanTerbaik"picture book is a qualitative research with a focus to describe and to explain the visual elements contained on the pop-up page in a "LiburanTerbaik"picture book, which views based on color, line, shape, space, texture and typeface. Data collection technique utilized observation that is focused on the pop-up page in a "LiburanTerbaik" picture book. 


\section{RESULT AND DISCUSSION}

\subsection{History of Rabbit Hole Publisher}

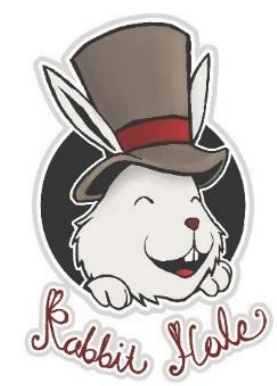

Figure 1. Rabbit Hole Publisher Logo

PT. LubangKelinci Indonesia (Rabbit Hole) began in 2013. Devi Raissa, author of Rabbit Hole, who is also a child psychologist often finds parents who complain about the difficulty of communicating with children. In fact, poor communication between father, mother and child will lead to various problems. Based on research, when reading a book, a child feels more comfortable and openly telling stories. It is important to remember too, make sure the book is good quality and according to age. However, it's often an obstacle. Good quality of books for children are mostly imported and expensive. There's not a lot of local production quality books that have affordable prices.

When it began in 2013, Rabbit Hole made a limited number of customized. Usually, it is ordered for a child's birthday. Devi made a story, and illustrated by her partner, Guntur Gustanto. Starting in 2014, Rabbit Hole changed the concept to publishing mass books that were still produced and distributed by themselves online, with the name @ rabbithole. The concept and appearance of the book page are made very attractive so they become interactive books. For example, the child is became the character. He can put up letter stickers, cut out, and stick to identity pictures. Then, there is the lift the flap and pop-up pages. Some Rabbit Hole products, such as Cilukba!,HOP!, SuaraApaItu?, AsalMulaNamaku, LiburanTerbaik, Kado yang Menyenangkan, andBella danBalonMerah.

\subsection{Analysis of Visual Elements Pop-up Pages in "LiburanTerbaik" Picture Book}

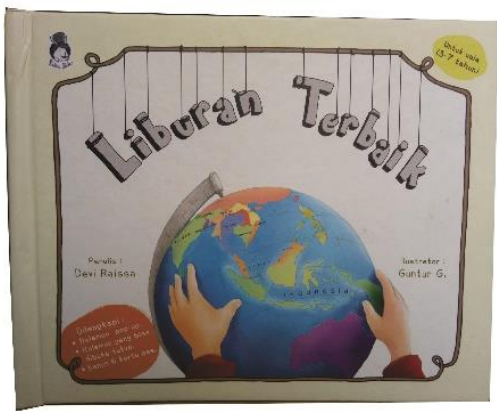


Figure 2. "LiburanTerbaik" Picture Book Cover

"LiburanTerbaik" picture book is a graphic media that contains elements such as color, line, shape, space, texture and typeface. From the design side, the augmented reality media pop up already represents the child visual needs in the learning process as this book accends to the visual side of the text [7]. This element is combined to form a combination of signs containing the message to be delivered by the author. In this picture book, it has 3 pop-up pages, which are in the form of Prambanan Temple, Jailolo Bay Festival, and also a rainbow. This pop-up media is a unique and interesting media that is suitable for children to bring creativity and add insight about the science of processing paper like origami. Origami is the Century-old art of folding paper. Another hundreds of old art of folding paper is a pop-up book. For a pop-up book designer, the important thing is to design a paper between two covers, and make the book able to be opened and closed[8].
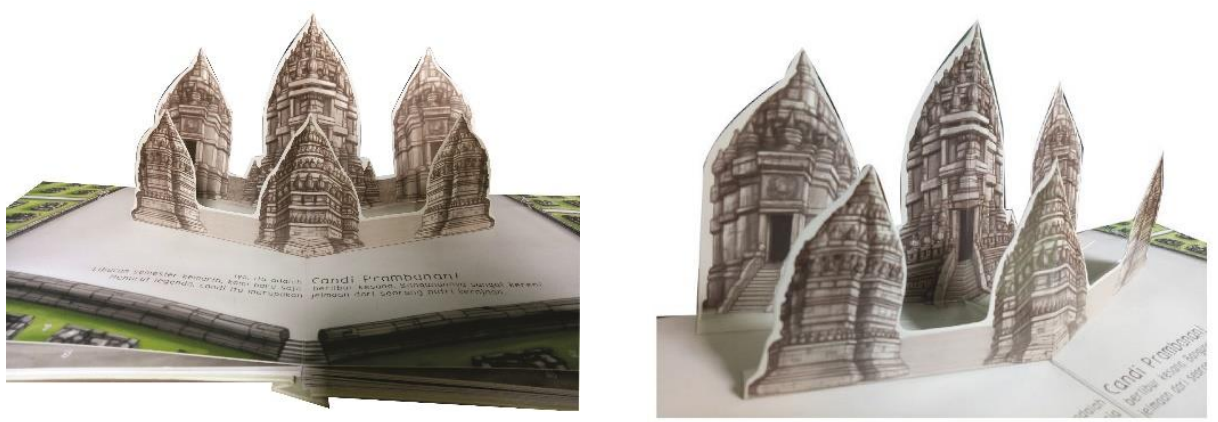

Figure 3. Prambanan Temple Pop-up Page

In this case the material used as research is a pop-up page in "LiburanTerbaik" picture book, whose illustrations can be arised by combining it on 2 pages. The illustrations on the pages of Prambanan Temple and the Jailolo Bay Festival use manual sketches and then processed in a computer. The illustration shown is the view of Prambanan Temple and Jailolo Bay Festival which are seen from the front, so that the surrounding background can be seen. As it can see on figure 3, on the Prambanan Temple page, the pop-up forms displayed are 6 temple buildings that stand in 2 rows. The illustration of Prambanan Temple is illustrated by a combination of horizontal-vertical lines, so that it gets the figure of piles of stones and also stairs. Also thick-thin lines that show the rough texture of the stone.Line and texture can conjure or depict the following looks of media or materials [9]. To further clear the illustration, the colors used resemble the original colors of Prambanan Temple, which is graybrown. The other than, the dark-bright side is given in these color to show its dimensions. Mentioned that, colors on the page should reflect the character's feelings and thoughts; show the impact of the story and render this impact more impressive using light-dark contrast[1]. The basic picture on the pop-up page of Prambanan Temple to describe the wall surrounding of Prambanan Temple, with the visual elements displayed no different from the pop-up illustrations. And in outside the wall there is a green color that describe an expanse of grass, with small temples around Prambanan Temple. 

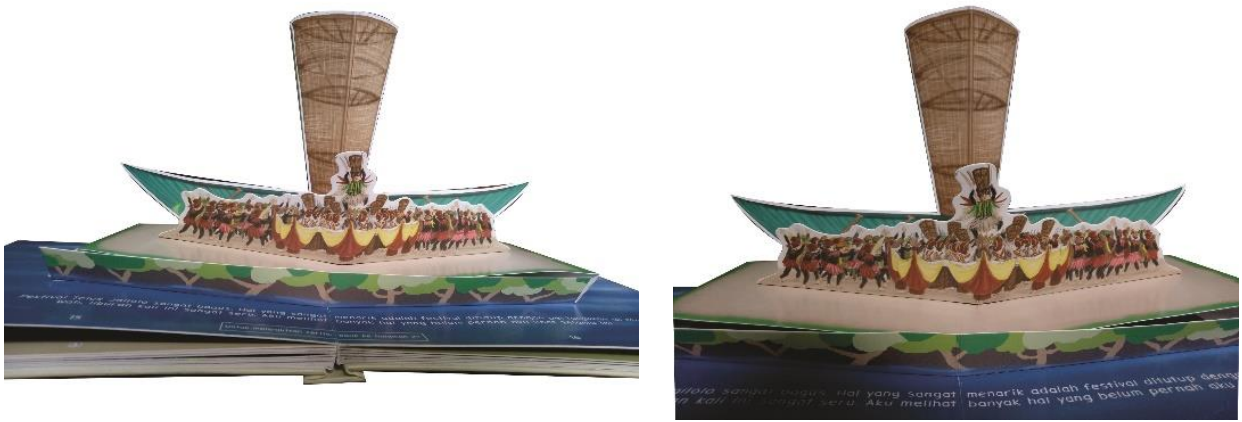

Figure 4. Jailolo Bay Festival Pop-up Page

Different with the Prambanan Temple, on the Jailolo Bay Festival page we like to see from the sea. The pop-up form that is displayed is a picture and atmosphere during the festival. There are three forms of Jailolo Bay Festival pop-up illustrations, that is islands with trees, people who are dancing and also a boat-like setting (in figure 4) that means the purpose of this festival is a greatfull to God for the produce of the earth and cleaning the sea of dirt so that the produce will always be abundant. The three forms of pop up on this page, layered. Layers used to overlap multiple variables to create a direct relationshipin physical space[10].The figure of an island with trees uses only 3 green colors to describe leaves and brown that describe tree trunks, without using lines so it does not reveal the texture. In the second form, people who dance in general use bright colors like red, yellow, green, and brown that describe the excitement of the event. Like the figure of trees, the figure of the people who dance also there is no clear line, it's just cannot seem to be a texture and also the rhythm with the use of color gradations. And the last is a large boat figure which can be seen from the comparison of the size of the boat with the person. The boat is described in dark green with a rhythm line with an older green color like the texture. On the boat there are also 4 images of light brown oars, and images that resemble waves are light green and dark green. In addition, behind the boat is also illustrated a case of a very large wicker basket. The figure of the wicker basket is like a tube that shrinks down, with light brown and dark brown colors. Woven texture is seen from horizontal and vertical lines that overlap each other. The basic picture on this pop-up page describes a blue sea with a little white gradation.
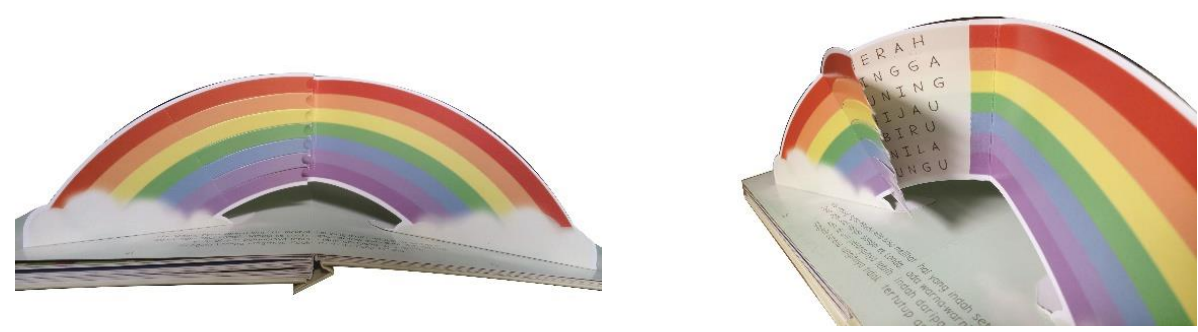

Figure 5. Rainbow Pop-up and Lift the Flap Page 
The last pop-up page is a rainbow shape. Illustration in a rainbow pop-up page using a computer sketch, so the colors of the rainbow displayed are also clearer. Color applied to draw attention, to label, to show relationships, or toindicate a visual scale of measurement[10]. This rainbow pop-up page not only displays pop-up, but also lifts the flap on its rainbow illustration itself which explains the colors of the rainbow that can be seen in figure 5 . The figure of the rainbow consists of a combination of 7 color lines that are curved in a semicircle, and at the end of the curve there are white clouds graded from thin to dark. The basic image on the rainbow pop-up page is light blue with white gradations that describe the sky. Typeface that is used on the 3 pop-up pages is the same, both from the font type and size, which differentiates only color by adjusting to primary color. The font used is not stiff, like handwritting and easy to read for all people. As in previous research described that, the teachers' belief that letters for beginning readers should look as simple as possible and should reflect handwriting is falsified by this study[11].The font size is also suitable, not too big and not too small. Besides that, the contents of this illustrated story book are not too many, only 2 to 4 lines are in accordance with the target of this illustrated storybook, namely children.

\section{CONCLUSION}

The results of this research, the three pages of pop-up already have visual elements.Of the color elements, all three pages of pop-up use attractive, vivid colors, and use the original color of the illustration. Line elements, not all of pop-up's illustrations have lines that are tough and clear. So in JailoloBay Festival page and rainbow page see no texture. But although not all illustrations have lines, the shape meant in the illustration remains clearly formed. And the latter typefaces that is used also has been obvious that it has been described, especially for the target in the book, children.

\section{REFERENCE}

[1] E. Çer, "Preparing Books for Children from Birth to Age Six: The Approach of Appropriateness for the Child," vol. 7, no. 6, pp. 78-99, 2016.

[2] E. N. O. Reilly, M. B. Bacha, M. H. Haley, C. Fan, and B. Li, "Theory and Practice in Language Studies," vol. 4, no. 7, 2014.

[3] P. Shannon and B. G. Samuels, "Developing an Understanding of Literacy through Production of Pop-Up Books," vol. 25, no. 3, 1985.

[4] F. Serafini, "Expanding Perspectives for Comprehending Visual Images in Multimodal Texts," vol. 54, no. February, pp. 342-350, 2011.

[5] L. A. Prior, A. Willson, and M. Martinez, "PIC T U RE T H IS," pp. 195-207, 2012.

[6] M. Nikolajeva, “AND EMOTIONAL LITERACY," vol. 67, no. 4, pp. 249-254, 2013.

[7] M. A. Nazaruddin and M. Efendi, "The Book of Pop Up Augmented Reality to Increase Focus and Object Recognition Capabilities for Children with Autism," vol. 2, no. $1,2018$.

[8] R. T. S. Uehara, "The complexity of a Pop-up book," vol. 2006-AL(1, pp. 59-64, 2006.

[9] R. Landa, Graphic design solutions, 4th Editio. Cengage Learning, 2010.

[10] L. S. Davis, "Improving Visual Communication of Science Through the Incorporation of Graphic Design Theories and Practices Into Science Communication," no. January, 2015.

[11] A. Bessemans, "Matilda : a typeface for children with low vision," no. June, 2018. 
